\title{
Project Management in Public Health: A Systematic Literature Review on Success Criteria and Factors
}

\author{
Carolina Santos $^{a}$ Vitor Santos $^{b}$ António Tavares $^{c}$ João Varajão ${ }^{d}$

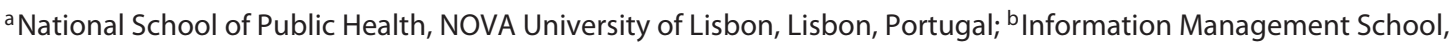

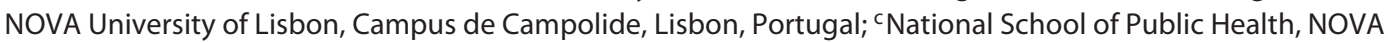 \\ University of Lisbon, Lisbon, Portugal; ${ }^{d}$ Department of Information Systems, ALGORITMI Center, University of \\ Minho, Campus de Azurém, Guimarães, Portugal
}

\section{Keywords}

Success factors - Success criteria - Project management ·

Public health $\cdot$ Health planning $\cdot$ Health services

management

\section{Abstract}

Background: Success is a central concept in project management (PM), yet the literature is relatively extensive and generalist concerning topics related to PM success. Several metrics and factors that influence the success of a project are common to diverse industries, although there are also particularities. In the case of projects and programs developed by public health action, the focus is on protection of the health of specific target groups or populations, and many of them are concerned with survival issues. Summary: As the result of a systematic literature review, this paper identifies general project success criteria and success factors and describes specific evidence for the public health field. Key messages: The success of public health projects needs to be managed systematically and evaluated with a set of comprehensive success criteria.

(c) 2020 The Author(s). Published by S. Karger AG, Basel on behalf of NOVA National School of Public Health

\section{Karger $\stackrel{\text { ' }}{=}$}

karger@karger.com

www.karger.com/pjp

Karger

Open access on behalf of NOVA National School of Public Health

This article is licensed under the Creative Commons AttributionNonCommercial-NoDerivatives 4.0 International License (CC BY NC-ND) (http://www.karger.com/Services/OpenAccessLicense) Usage and distribution for commercial purposes as well as any distribution of modified material requires written permission.
(C) 2020 The Author(s). Published by S. Karger AG, Basel

\author{
Gestão de Projetos de Saúde Pública: Uma Revisão \\ Sistemática de Literatura Sobre Critérios e Fatores de \\ Sucesso
}

\section{Palavras Chave}

Fatores de sucesso · Critérios de sucesso - Gestão de projetos · Saúde pública · Planeamento em saúde ·

Gestão de serviços de saúde

\section{Resumo}

Contexto: O sucesso é um conceito central em gestão de projetos (GP), pelo que a literatura é relativamente extensa e generalista em relação aos tópicos relacionados com o sucesso da GP. Pese embora um conjunto alargado de métricas e fatores influenciadores do sucesso dos projetos seja comum a diversas indústrias, existem também particularidades. No caso dos projetos e programas de saúde pública, o foco encontra-se na proteção da saúde de grupos específicos ou populações, encontrando-se os mesmos frequentemente relacionados com questões de sobrevivência. Resumo: Através de uma revisão sistemáti-

Carolina Santos

National School of Public Health, NOVA University of Lisbon Ave. Padre Cruz

PT-1600-560 Lisbon (Portugal)

c.santos@ensp.unl.pt 
ca da literatura, o presente artigo identifica os critérios e fatores de sucesso gerais dos projetos e fornece evidência específica para o setor da saúde pública. Mensagenschave: O sucesso dos projetos de saúde pública necessita de ser gerido de forma sistemática, e avaliado tendo por referência um conjunto bem definido de critérios de sucesso.

(c) 2020 The Author(s). Published by S. Karger AG, Basel on behalf of NOVA National School of Public Health

\section{Introduction}

A project is a temporary organization to which resources are assigned to deliver beneficial change. It is a useful way to introduce innovations, address new needs, or find solutions to problems that the status quo does not accommodate [1]. During the last 3 decades, "success" has been explored as a central theme in project management (PM) literature, and extensive investigations have been conducted, especially for the construction, engineering, and software development industries.

Success is a multidimensional concept, described in a more objectivist or subjectivist paradigm, and it is influenced by a set of cultural, leadership, project, management, and behavioral factors [2]. Regarding success, attempts toward harmonization are often seen as negative, as they sketch a generalist view of factors related to $\mathrm{PM}$ and do not consider the particular environment of the projects and the special attributes of the industries [3], potentially leading to the omission of important aspects.

Public health is concerned with assessment and monitoring of the health of communities and populations at risk, formulation of public policies to solve identified problems, and setting of priorities. It works towards appropriate and cost-effective care for all, including health promotion and disease prevention services [4]. In this context, quality is a key matter, as many projects are concerned with survival issues, the government is commonly a stakeholder, and public funding plays a central role [5].

The success of a public health project mainly depends on its global impact on the target population, although this is not easy to measure as the results are frequently not tangible. This difficulty in measuring effects represents a considerable challenge for project and program managers.

Although the specificities of public health are easy to recognize, PM literature rarely documents public health projects. From a professional and academic point of view, it is important to understand the success and failure of projects in their context, so studying success in public health action is a relevant issue. This paper aims to characterize the state of the art concerning project success criteria and factors and to provide fundamental knowledge for the management of public health projects, and it is a kick-off point for empirical research. The next section identifies the results of the literature review.

\section{Methods}

A systematic literature review was conducted between September and December 2018. The search was limited to articles published in the last 4 decades. Editor databases were consulted on the web using PubMed Central, PubMed, Google Scholar, B-on, Web of Science, Emerald, and Scopus. The following keywords were applied and combined: "project management," "success," "success factors," "success criteria," "health," and "public health." The full search strings applied are presented in Appendix 1. Abstracts and titles were used to determine whether the reference might be relevant, and full texts of potentially relevant articles were downloaded. The references of retrieved articles were checked for any further relevant citations.

The research was conducted with the aim of finding evidence concerning the variables that influence the success achieved, although articles focused on "failure factors" were not excluded. Titles and abstracts were analyzed concerning the eligibility criteria. Publications which analyzed success in a specific sector (e.g., banking, engineering, and information technology) or in a particular context (e.g., virtual projects, outsourcing services, and supply chain management) were excluded, and the search for evidence was intensified in the health field by checking the full reference list of each article. Duplicate records of the same document were removed. The authors registered 43 eligible papers, with 35 being generalistic, aiming to identify traditional success criteria and factors (Fig. 1). All of the papers included in the research were retrieved from reputed journals, increasing the probability that the applied methods were appropriate for each different type of study (literature review, research article, and perspective article). These papers were published mainly in the International Journal of Project Management and the Project Management Journal (Table 1). Eight references are linked to public health; all of them were published in different journals, and 2 develop the topic "project success criteria." Most of the articles were published in the 2000s (Fig. 2). Only 1 paper, published in BMC Public Health, focuses on public health success factors from a PM perspective.

The next section describes the findings of the review by presenting a critical analysis of the success phenomenon and the meanings given to PM success or project success in the PM literature. A description of each success criterion and factor is given and the list of references is presented, including the year of publication and the type of article. A retrospective look at the development of the field is also shown.
38

Port J Public Health 2020;38:37-48 DOI: $10.1159 / 000509531$
Santos/Santos/Tavares/Varajão 


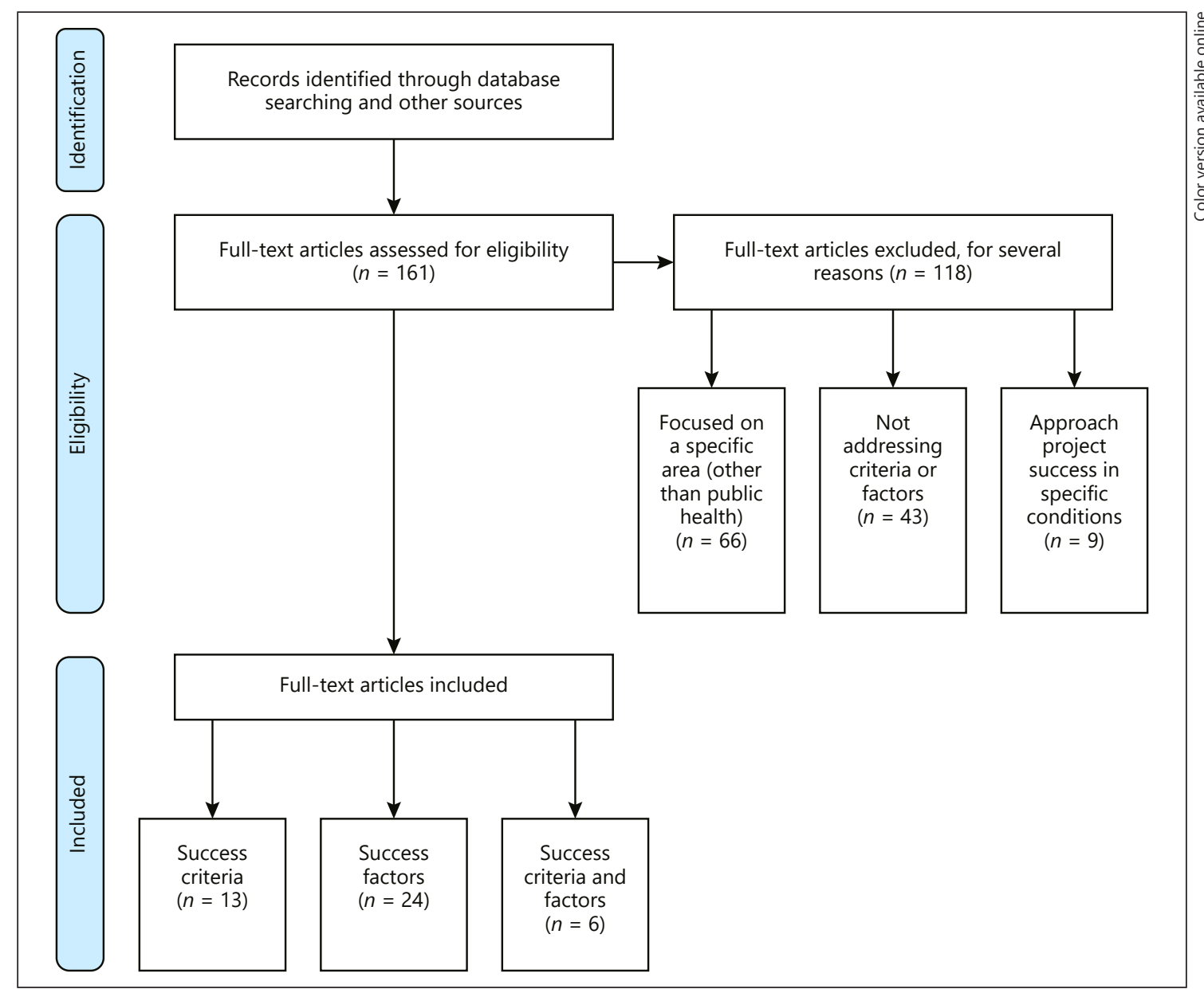

Fig. 1. Systematic literature review process.

Table 1. Non-context-specific success criteria and factors: number of articles published per journal

\begin{tabular}{llllr}
\hline & $\begin{array}{l}\text { International Journal of } \\
\text { Project Management }\end{array}$ & $\begin{array}{l}\text { Project Management } \\
\text { Journal }\end{array}$ & Others & Total \\
\hline Success criteria and factors & 6 & - & - & 6 \\
Success criteria & 6 & 3 & 3 & 12 \\
Success factors & 9 & 2 & 6 & 17 \\
\hline Total & 21 & 5 & 9 & 35 \\
\hline
\end{tabular}

\section{Results}

\section{Success Criteria and Factors}

Concerning project success criteria, 8 studies were literature reviews, 11 were research articles, and there were no perspective articles (Table 2). All of the articles discuss project success, either implicitly or explicitly, as more complex than PM success, taking criteria other than time, cost, and quality into consideration in their definitions of success.

While project success is measured by the achievement of goals and generation of the desired outputs and outcomes, PM success is perceived as a good performance on the traditional cost, time, and quality measures, being 


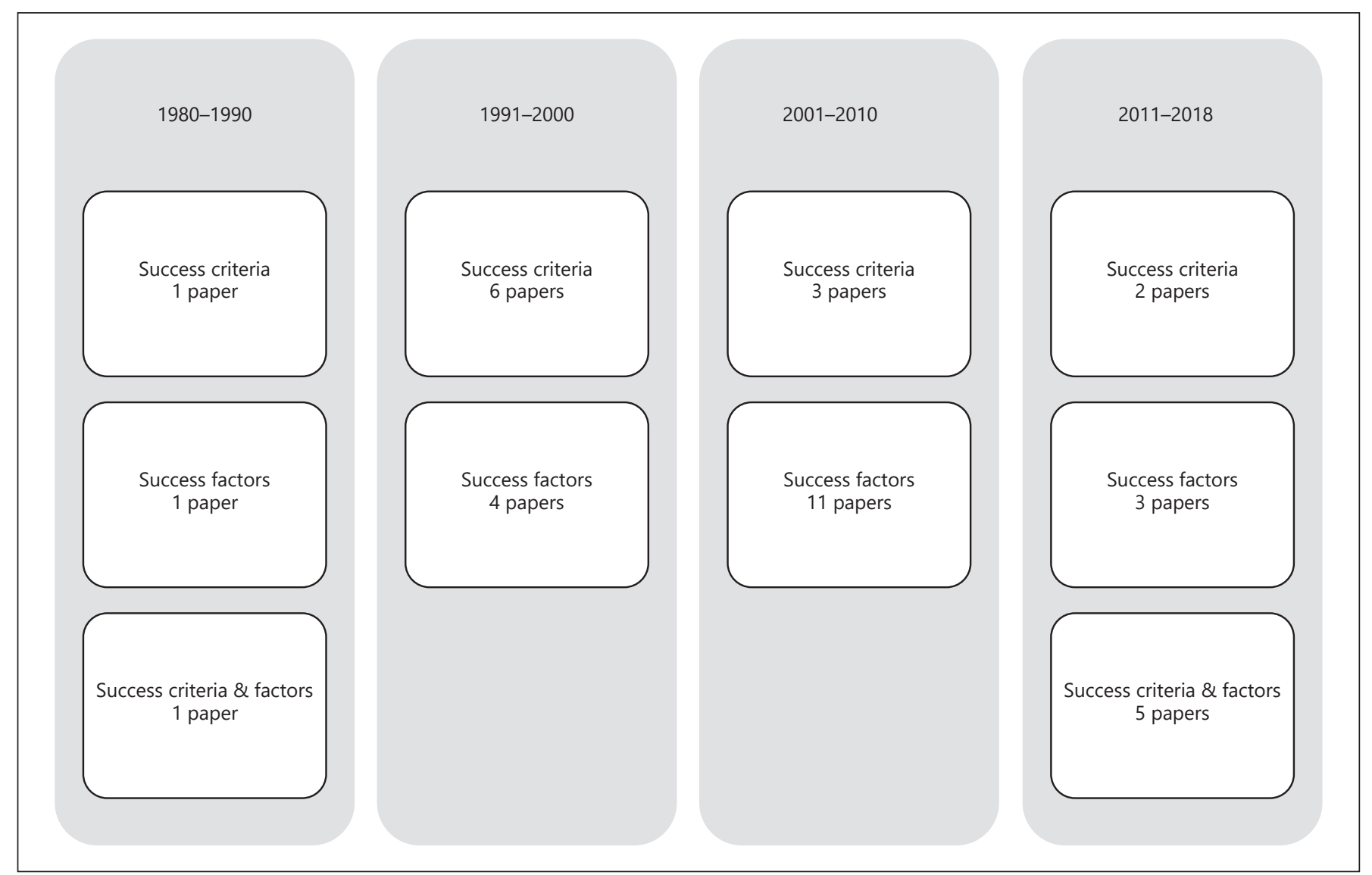

Fig. 2. Success criteria and factors: number of articles published per period.

easier to measure $[6,15]$. The success of PM can lead to project success, but the opposite is not true, i.e., it is reasonable to accept that failure in PM can lead to project failure, except in fortuitous circumstances, but projects may fail despite successful PM [8].

Project success is dependent on teams, clients, and stakeholders' perceptions [25, 26]. During the famous period of the triangle of virtue in PM, customer contact was minimal after the delivery of the final product, long-term follow-up and troubleshooting was not a common practice, and measures that involved looking for the benefits or effectiveness of the project from the perspective of stakeholders were not available [27]. At the end of the 1980s, the PM literature focused success on client satisfaction and the perspectives of key stakeholders (clients, managers, team members, and investors) [10]. In the late 1990s, Munns and Bjeirmi [28] described the client as the main party concerned with the success of the project in the long term. Freeman and Beale [15] identified the fol- lowing main criteria to measure project success: technical performance, efficiency in project execution, organizational and management outputs (including customer satisfaction), personal growth, project completion, technical innovation, business performance, and the feasibility of manufacturing. Wideman and Shenhar [8] discussed the strong relationship between project success and customer satisfaction and argued that project effects should be measured in a different timeframe, i.e., project goals during project execution, customer benefits in the short term, project direct contribution in the medium term, and future growth opportunities in the long term. A broader perspective that conceived projects as major vehicles for organizational and societal prosperity was settled by Shenhar et al. [9]. The model proposed the following 4 time-dependent dimensions to assess project success: project efficiency (completion on time and budget), impact on the customer (meeting performance measures, functional requirements, real needs, and customer satis- 
faction), business and direct success (increasing business results and gaining market share), and preparing for the future (preparing the infrastructure for future opportunities, markets, ideas, innovations , and products). Also, Ika [29] emphasized efficiency and effectiveness measures in assessing project success.

Bourne and Walker [30] reinforced the perception paradigm of project success by highlighting the value of reading the power structures of the organization, i.e., those who can influence the global perception of project success. Other authors linked project success to the contributions for the mission of the organization and the short and long-term goals of the company [29, 31]. Jaafari [32] focused the accomplishment of project outcomes regarding project strategic objectives, i.e., its viability as a business entity, criticizing the traditional view of management fostered in PMBOK [33] by minimizing the PM focus to the implementation of processes and activities. Furthermore, Perminova et al. [34] argued that the traditional PM approaches still place a great emphasis on assuring compliance with time, budget, and scope constraints, leaving behind some considerations and solutions to deal with uncertainty and risks, such as continuous improvement, customer-centric thinking, knowledge generation, information sharing, and reflective learning about the experience. Winter and Szczepanek [17] introduced the crucial dimension of value creation, i.e., a more value-centric paradigm that mobilizes customers and stakeholders to create their own value from the various offerings of the project or program instead of focusing on the primary capital asset, system, or facility [24]. At the beginning of the 2010s, a review [35] summarized the following general criteria for assessing project success:

- achievement of scope, time, and cost goals: estimates provided for the "triangle of virtue" at the end of the project;

- meeting customer and sponsor expectations: satisfaction of the end-users and sponsor; and

- achievement of strategic project goals.

In summary, the research progress has shown that criteria other than time, cost, and quality need to be considered in measuring project success (Table 3). Recent literature places a great emphasis on customer and stakeholder satisfaction $[20,25,26]$ but also supports the idea that this fulfillment of expectations has a strong relationship with performance on the dimensions of the iron triangle, so finishing "on time" and "on budget" is mandatory $[21,23]$. It further supports that it is not possible to develop an exhaustive list that will fit all projects, as suc-
Table 2. General success criteria and factors: type of articles

\begin{tabular}{|c|c|c|c|}
\hline Study & $\begin{array}{l}\text { Literature } \\
\text { review }\end{array}$ & $\begin{array}{l}\text { Research } \\
\text { article }\end{array}$ & $\begin{array}{l}\text { Prospective } \\
\text { article }\end{array}$ \\
\hline \multicolumn{4}{|l|}{ Success criteria } \\
\hline De Wit [6] & $\mathrm{X}$ & & \\
\hline Baccarini [7] & $\mathrm{X}$ & & \\
\hline Wideman and Shenhar [8] & & $\mathrm{X}$ & \\
\hline Shenhar et al. [9] & & $\mathrm{X}$ & \\
\hline Stuckenbruck [10] & $\mathrm{X}$ & & \\
\hline Lim and Mohamed [11] & $\mathrm{X}$ & & \\
\hline Westerveld [12] & & $\mathrm{X}$ & \\
\hline Bryde and Robinson [13] & & $\mathrm{X}$ & \\
\hline Atkinson [14] & $\mathrm{X}$ & & \\
\hline Freeman and Beale [15] & $\mathrm{X}$ & & \\
\hline Qureshi et al. [16] & & $\mathrm{X}$ & \\
\hline \multicolumn{4}{|l|}{ Winter and Szczepanek [17] X } \\
\hline Andersen [18] & $\mathrm{X}$ & & \\
\hline $\begin{array}{l}\text { Berssaneti and Carvalho } \\
\text { [19] }\end{array}$ & & $\mathrm{X}$ & \\
\hline Davis [20] & & $\mathrm{X}$ & \\
\hline Williams et al. [21] & & $\mathrm{X}$ & \\
\hline Serrador and Pinto [22] & & $\mathrm{X}$ & \\
\hline Haverila and Fehr [23] & & $\mathrm{X}$ & \\
\hline Andersen [24] & & $\mathrm{X}$ & \\
\hline Total & 8 & 11 & 0 \\
\hline
\end{tabular}

Success factors

Pinto and Slevin [37]

De Wit [6]

Belassi and Tukel [25]

Standish Group [38]

Abdulla [39]

Davis [40]

Munns and Bjeirmi [28]

Diallo and Thuillier [41]

Khang and Moe [42]

Edward et al. [43]

Westerveld [12]

Tansley and Newell [44]

Glaser [45]

Simpson [46]

Yalegama et al. [47]

Berssaneti and Carvalho

[19]

Golini et al. [48]

Ika and Donnelly [49]

Williams et al. [21]

Serrador and Pinto [22]

Haverila and Fehr [23]

Chen and Lin [50]

Total

0]

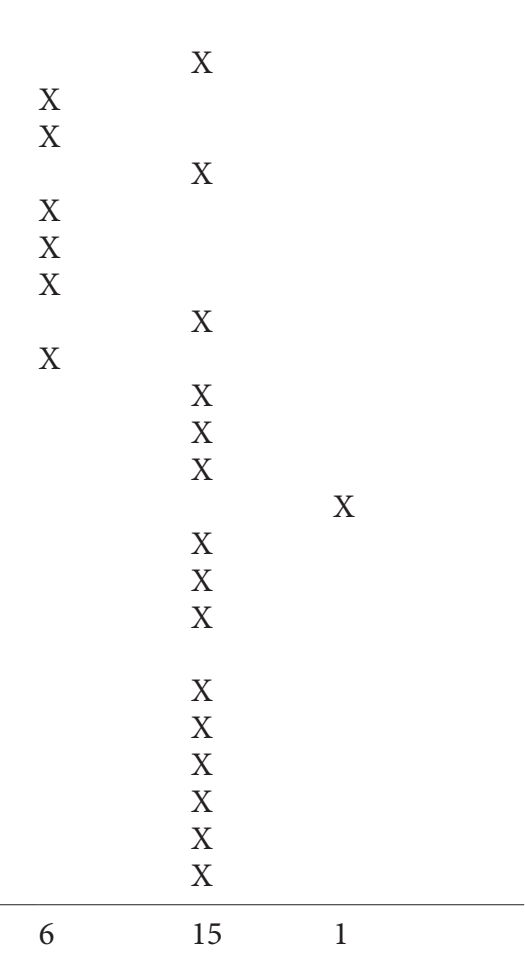


Table 3. General project success criteria: description

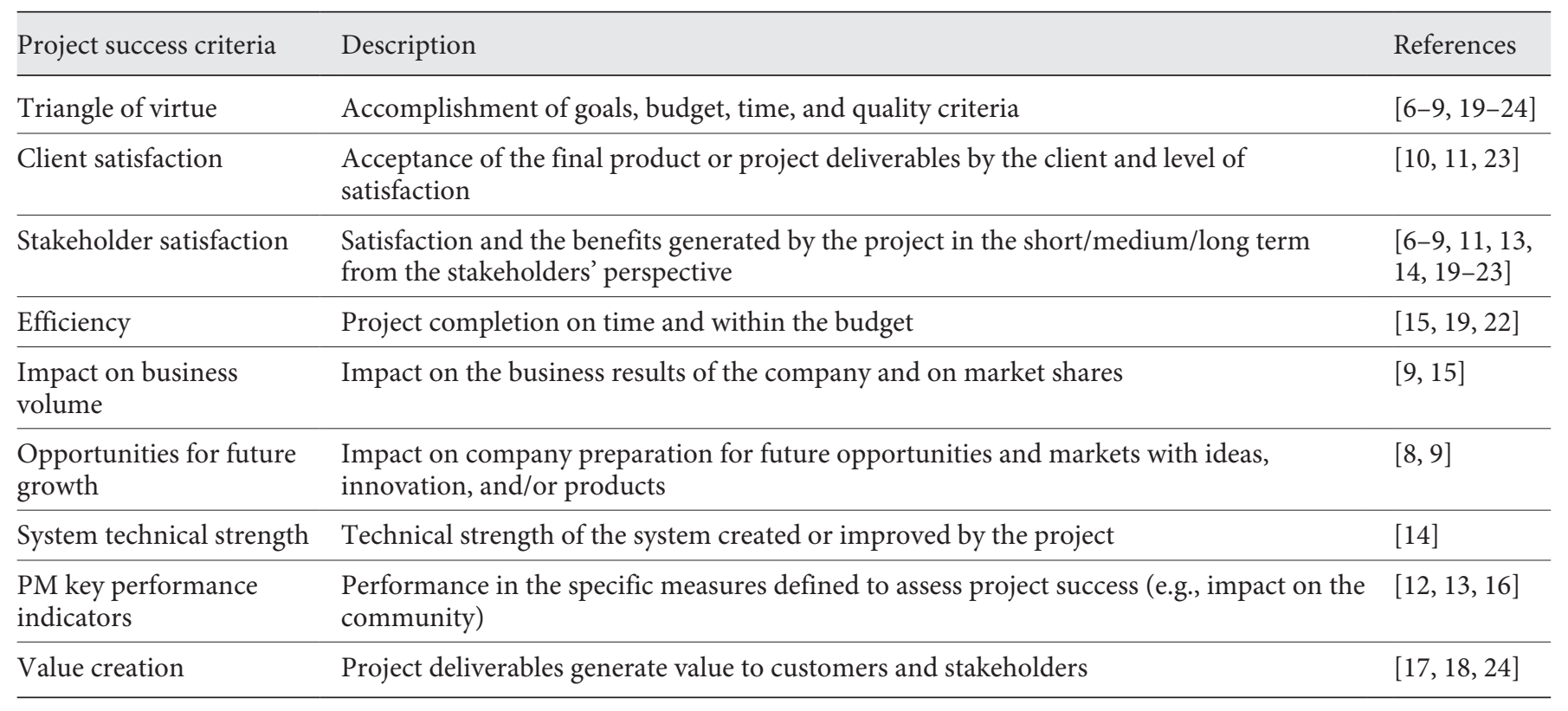

cess criteria differ so much due to variables such as project scope, environment, uniqueness, and complexity [24, 25].

Still, concerning project success, many research efforts have been made to find evidence about success factors, i.e., the inputs of the management system that directly or indirectly influence the success of the project or business [36]. On this theme, 6 of the eligible papers were categorized as literature reviews, 15 as research articles, and 1 as a perspective article (Table 2).

After more than 40 years of intensive research, there is a vast amount of knowledge regarding the generalist factors that enhance the success of a project. Nowadays, researchers are focusing on specific types of projects and contexts and analyzing empirical relationships between success criteria and factors more than contributing with new inputs to a list of non-context-specific success factors, as several theoretical models are already available. One of the most visible actors of success (or failure) is the project manager, so studies typically asked them about the variables that have an impact on project success, usually by survey and applying a Likert scale. The results of the literature review on this issue are summarized in $\mathrm{Ta}$ ble 4 .

From this literature review, it is important to mention particularly the research of Pinto and Slevin [37] and Belassi and Tukel [25] because they offer interesting perspectives about using information related to success fac- tors. First is the idea that the relevance of each success factor changes according to a project's phases. That is, factors such as the project mission, top management support, project planning, and definition of the project goals are crucial in the project planning phase; factors such as customer engagement, the performance of the project team, customer involvement, monitoring and feedback, communication, and problem-solving are crucial at the implementation phase and have a tactical dimension since they are related to resource utilization (human, technical, and financial) for the achievement of strategic goals [37]. Second is the idea that the relevance of each success factor is linked to the relative weight of each project success criteria. For example, resources availability may be more important than top management support to accomplish the project with the quality initially defined, whereas if the focus is to accomplish the project on time then PM skills and good communication processes within the project team are both fundamental dimensions [25].

\section{Public Health Success Criteria and factors}

Concerning public health success criteria, the only 2 eligible papers of this literature review are research articles $[51,52]$, which provide exploratory knowledge that needs to be confirmed by extra empirical evidence. These papers highlight the relevance of the project's impact on the community and in policy and system changes. Con-
Santos/Santos/Tavares/Varajão 
Table 4. General project success and failure factors: description

Summary description

References

Success factors

Mission, vision, and goals Clearly defined project mission, goals, business goals, and strategy and global commitment to achieving them

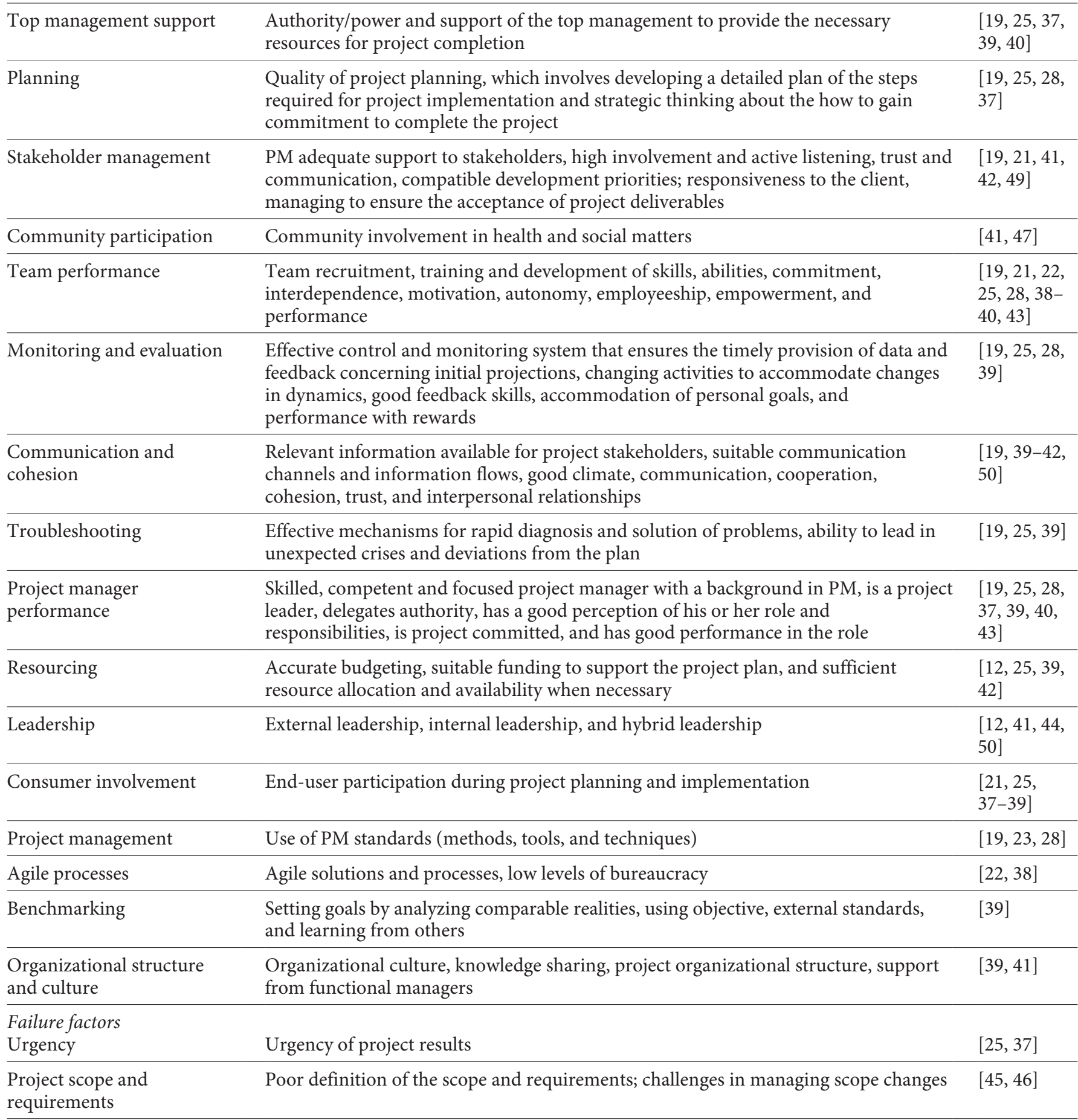

PM in Public Health: Success Criteria and Factors
Port J Public Health 2020;38:37-48

DOI: $10.1159 / 000509531$
$[25,37-40]$

$[19,25,37$, $39,40]$

$[19,25,28$,

37]

$[19,21,41$,

$[41,47]$

$[19,21,22$,

$25,28,38$

$40,43]$

$[19,25,28$

39]

$[19,39-42$,

$[19,25,39]$

$[19,25,28$

$37,39,40$,

$[12,25,39$,

42

$[12,41,44$,

$[21,25$,

[39]

$[39,41]$

$[45,46]$ 
Table 4 (continued)

Summary description

References

\begin{tabular}{ll}
\hline Project benefits & Little evidence of benefits arising from the project \\
\hline Top management support & Insufficient top management support for project implementation \\
\hline Organizational culture & Organizational inertia and lack of corporate incentives for PM \\
\hline Change management & Organization is resistant to change \\
\hline Culture and values & Lack of honesty \\
\hline Leadership & Leadership is intolerant to bad news \\
\hline Project complexity & Project complexity level is too high, difficult to manage \\
\hline Planning & Unrealistic deadlines or expectations \\
\hline
\end{tabular}

Table 5. Public health success factors: type of articles

\begin{tabular}{lll}
\hline Study & $\begin{array}{l}\text { Literature } \\
\text { review }\end{array}$ & $\begin{array}{l}\text { Research } \\
\text { article }\end{array}$ \\
\hline $\begin{array}{l}\text { Success factors } \\
\text { Rifkin et al. [55] }\end{array}$ & $\mathrm{X}$ & \\
$\begin{array}{l}\text { Cheadle et al. [53] } \\
\text { Tempfer and Nowak [56] }\end{array}$ & $\mathrm{X}$ & $\mathrm{X}$ \\
$\begin{array}{l}\text { Dwyer et al. [57] } \\
\text { Paré and Trudel [58] }\end{array}$ & $\mathrm{X}$ & $\mathrm{X}$ \\
$\begin{array}{l}\text { Payne et al. [51] } \\
\text { Medlin et al. [52] }\end{array}$ & & $\mathrm{X}$ \\
Suhonen and Paasivaara [59] & & $\mathrm{X}$ \\
\hline Total & 3 & $\mathrm{X}$ \\
\hline
\end{tabular}

cerning project success factors, the majority of publications $(n=5)$ were categorized as research articles. A high heterogeneity was found between the studies' design, methodologies, and data collection methods (Table 5). Cheadle et al. [53] applied key informant interviews, partnership surveys, patient observation, and document review to identify the factors associated with partnership success for public health initiatives. Paré et al. [58] addressed the success factors for the adoption of new medical technology in 2 Canadian hospitals by observation, stakeholder/professional interviews, and document review. Payne et al. [51] analyzed the researchers' opinions concerning the use of PM standards in a public health project by administering a self-administered questionnaire, composed of open and closed questions, to teams. Medlin et al. [52] conducted a qualitative analysis of selected case studies, which applied different collection methods, intending to identify the critical success factors that have contributed to the effective deployment of proven, cost-effective technologies and services in low-income settings. Success factors of the included papers were identified and are described as follows:

- community participation: the active participation and involvement of communities in public health initiatives $[52,54,55]$;

- organizational structure, culture, and climate: strategic directions, leadership, organization structure, culture and climate, people management, stakeholder management, strategic alliances, commitment to seeing it through, and agile processes (the excess of bureaucracy) [56];

- planning: early assessment of the project context, derivation of a substantive plan describing potential key challenges, a proactive strategy that takes into consideration all technological, technical, economic, organizational, and human factors, setting of realistic goals, appropriate strategies, good decision-making structures, and a focus on sustainable outcomes [51, 52, 56, 57];

- resourcing: financial viability, availability of the necessary human, financial, and material resources, realistic financing arrangements, the presence of competent suppliers, and enough decision-making power to oversee the acquisitions process [4, 52, 55-57];

- project manager performance: skills of the project manager, leadership, motivation, ability to coordinate resources, and use of the right methods and tools [51, 56];

- team performance: dedicated and talented staff, teamwork, motivation, absence of staffing issues related to recruitment and turnover [52, 56, 57];
Santos/Santos/Tavares/Varajão 
Table 6. Summary table: success criteria and factors

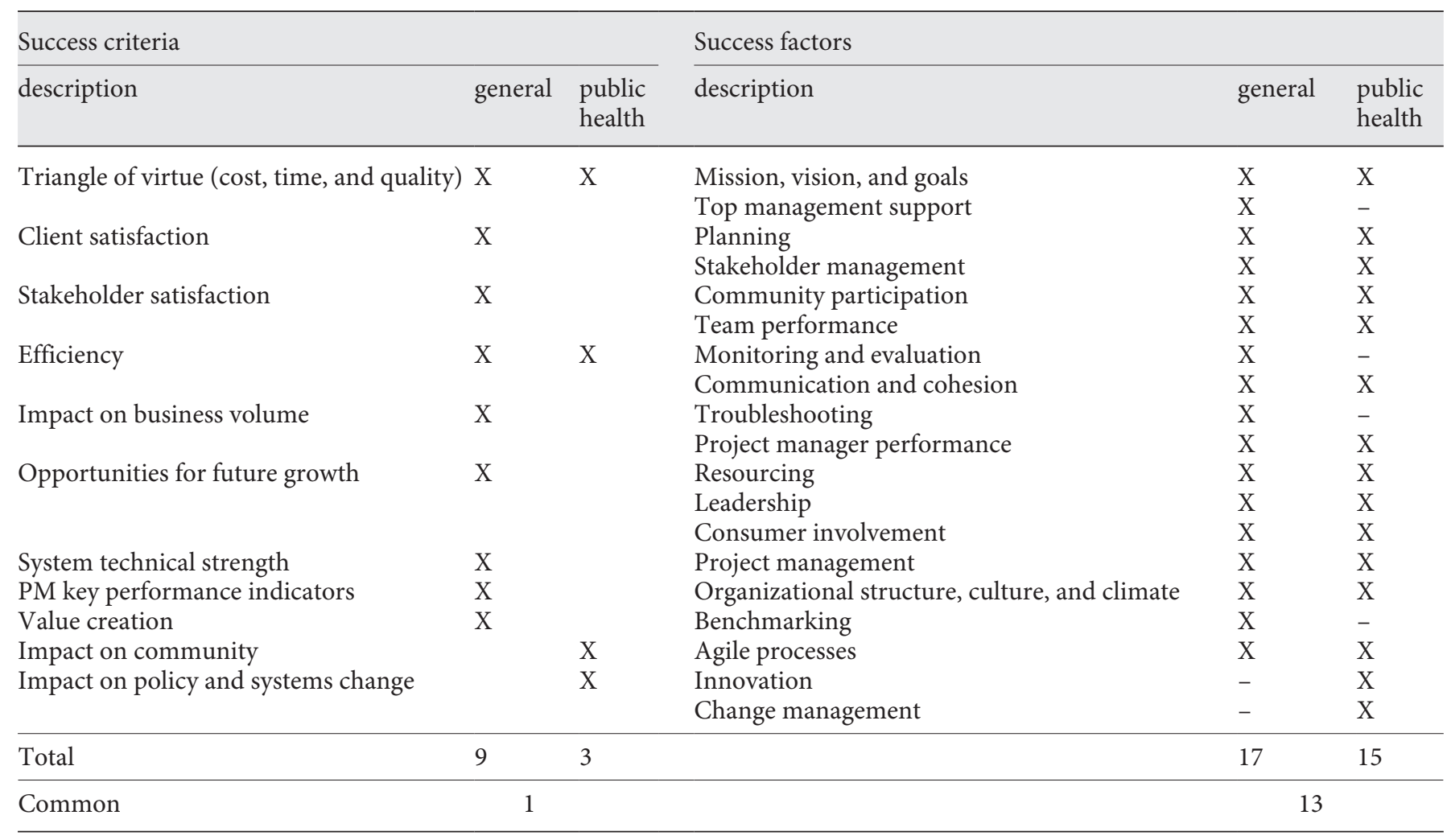

- leadership: ability to move individuals and groups toward the project goals and interests [4, 52];

- PM: effective PM and use of PM standards (methodology, tools, and techniques) [51];

- innovation: incorporation of new research findings and technical innovation [4];

- mission, vision, and goals: project goals, mission, and vision shared with all concerned parties [52, 56, 57];

- stakeholder management: active and sustained involvement of highly motivated actors with complementary skills and interests and partnerships with well-institutionalized consumer organizations $[4,56$, 57];

- communication and cohesion: adequate internal and external communications, open communication, and sharing of information $[52,55]$;

- change management: time and skills required to plan and implement policy change activities $[4,52,56]$; and

- consumer involvement: end-user participation during project planning and implementation [55].

\section{Discussion and Conclusion}

Despite the specificities of the public health sector, its economic and social significance in the global society, the high investments made by ministries of health in projects and programs that contribute to the National Health Plan, the European funding opportunities for crosscountry initiatives (e.g., 3rd Health Program), and the large number of private project-oriented organizations that operate in the market and have governments as clients, we found that there is a lack of systematized evidence concerning the success of public health action and the factors driving it.

It can be argued that public health is little permeable to the classical methods and metrics of PM, and 2 simple historical landmarks exemplify this. Just 12 years ago, the Centers for Disease Control and Prevention (CDC) launched a framework for PM success [60], and the relevance and applicability of PMBOK [33], a standard in $\mathrm{PM}$, have been recognized in long-term care management [61]; by the middle of 1940, after World War II, PM was already seen as a relevant discipline in multiple industrial sectors. 
The results of this research provide a set of non-context-specific success criteria and factors. Although the iron triangle is still essential, other mainly subjective success criteria, i.e., stakeholder satisfaction, benefits for the client or other stakeholders, and opportunities for future growth and value creation for the project owner, are nowadays also considered essential for successful PM [14]. The emphasis has shifted from PM success in the shortterm to project success in the short-term and long-term $[7,9]$, and multidimensional approaches emerged as central in PM research. As well, the focus of public health action has been on goals, community impact, and policy and system changes (Table 6), though with only a few short-term PM measures.

The results also suggest that, despite the important research efforts made in the last 30 years in identifying general success factors, there is insufficient literature that correlates the factors with success effectively achieved by projects, and even less in public health action. Considering the unique insights about public health dynamics provided by this literature review, conditions for further empirical research on theoretical models of success for public health projects were created. These studies should approach success from a PM perspective, with large samples, a variety of stakeholders, and distinctive types of projects and in a variety of public health settings.

There is also a gap between success factors and success assessment in practice that should be addressed by a success management knowledge area $[62,63]$. It would be interesting to create a project action framework that, based on empirical evidence at each stage of the project lifecycle, include the desirable actions for assessing and forecasting project success, defining priority actions and thus assisting project managers, directors and organizations in managing and evaluating project performance. With this type of PM action, it may be easier to propose and justify investments in PM governance structures, processes, and people in healthcare organizations.

Since success is a subjective, complex, and multidimensional concept, expressed in a variety of ways (e.g., not always using the word "success" or "failure"), our research method may have restricted the evidence found concerning public health projects (due, for instance, to the defined search strings). This limitation is recognized, although it was our goal to approach success from a PM perspective. So we believe that the specificities of the sector and the nature of the activity may explain some of the findings [5], and different maturity stages in the adoption of the PM discipline, tools, and frameworks may explain others [48].
In summary, the carried-out systematic literature review focused on an area of PM research that is little explored, rarely approached in a systematic way, and thus poor documented, i.e., the success criteria and factors of public health projects. This research contributes to the study of the management conditions that influence the success of public health projects and draws new avenues for further research.

\section{Conflict of Interest Statement}

The authors have no conflict of interests to declare.

\section{Funding Sources}

There were no funding sources for this study.

\section{Author Contributions}

Conception and design: Carolina Santos and João Varajão. Data acquisition: Carolina Santos. Data analysis and interpretation: Carolina Santos, João Varajão, Vitor Santos, and António Tavares. Drafting of this paper: Carolina Santos. Critical revision of the intellectual content: João Varajão, Vitor Santos, and António Tavares. Study supervision: João Varajão and António Tavares.

\section{Appendix 1}

Search Strings Applied

Project management AND success criteria

Project management AND success factors

Project management AND success

Success factors AND success criteria

Project management AND health

Project management AND public health

Project management AND success AND health

Project management AND success AND public health

Project management AND public health

Project management AND success factors AND public health

Success criteria AND public health

Success factors AND public health
Santos/Santos/Tavares/Varajão 


\section{References}

1 Turner J. The handbook of project-based management: leading strategic change in organizations. 3rd ed. London: McGraw-Hill; 2009.

2 Shore B. Systematic biases and culture in project failures. Proj Manage J. 2008;39(4):5-16.

3 OPSR. Improving programme and project delivery: UK Civil Service Report. London: Office of Public Services Reform; 2003.

4 World Health Organization. Public health services. 2014 [cited $2014 \mathrm{Feb} 21$ ]. Available from: http://www.euro.who.int/en/healthtopics/Health-systems/public-health-services.

5 Schwalbe K. An introduction to healthcare project management. 2013 [cited 2013 Sep 30]. Available from: http://kathyschwalbe. files.wordpress.com/2013/01/healthcarepm-chapter-1.pdf.

6 De Wit A. Measurement of project success. Int J Proj Manag. 1988;6(3):164-70.

7 Baccarini D. The logical framework method for defining project success. Proj Manage J. 1999;30(4):25-32.

8 Wideman RM, Shenhar AJ. Improving PM: linking success criteria to project type. In: Symposium "Creating Canadian Advantage through Project Management", Southern Alberta Chapter, Calgary, May 1996. Proceedings. Newtown Square: Project Management Institute; 1996.

9 Shenhar AJ, Levy O, Dvir D. Mapping the dimensions of project success. Proj Manage J. 1997;28(2):5-13.

10 Stuckenbruck L. Who determines project success? Proceedings of the 18th annual seminar/ symposium, Project Management Institute, Montréal, Canada, September 20-25, 1986, Bonaventure Hilton International, Château Champlain. Drexel Hill: Project Management Institute; 1986. p. 85-93.

11 Lim CS, Mohamed MZ. Criteria of project success: an exploratory re-examination. Int $\mathrm{J}$ Proj Manag. 1999;17(4):243-8.

12 Westerveld E. The project excellence modelR linking success criteria and critical success factors. Int J Proj Manag. 2003;21(6):411-8.

13 Bryde D, Robinson L. Client versus contractor perspectives on project success criteria. Int J Proj Manag. 2005;23(8):622-9.

14 Atkinson R. Project management: cost, time and quality, two best guesses and a phenomenon, it is time to accept other success criteria. Int J Proj Manag. 1999;17(6):337-42.

15 Freeman M, Beale P. Measuring project success. Proj Manage J. 1992;23(1):8-17.

16 Qureshi T, Warraich A, Hijazi S. Significance of project management performance assessment (PMPA) model. Int J Proj Manag. 2009; 27(4):378-88.

17 Winter M, Szczepanek T. Projects and programmes as value creation processes: a new perspective and some practical implications. Int J Proj Manag. 2008;26(1):95-103.
18 Andersen E. Value creation using the mission breakdown structure. Int J Proj Manag. 2014; 32(5):885-92.

19 Berssaneti F, Carvalho M. Identification of variables that impact project success in Brazilian companies. Int J Proj Manag. 2015;33(3): 638-49.

20 Davis K. An empirical investigation into different stakeholder groups perception of project success. Int J Proj Manag. 2017;35(4):60417.

21 Williams P, Ashill N, Naumann E, Jackson E. Relationship quality and satisfaction: customer-perceived success factors for on-time projects. Int J Proj Manag. 2015;33(8):1836-50.

22 Serrador P, Pinto K. Does Agile work? A quantitative analysis of agile project success. Int J Proj Manag. 2015;33(5):1040-51.

23 Haverila M, Fehr K. The impact of product superiority on customer satisfaction in project management. Int J Proj Manag. 2016; 34(4):570-83.

24 Andersen E. Do project managers have different perspectives on project management? Int J Proj Manag. 2016;34(1):58-65.

25 Belassi W, Tukel O. A new framework for determining critical success/failure factors in projects. Int J Proj Manag. 1996;14(3):14151.

26 Varajão J, Dominguez C, Ribeiro P, Paiva A. Failures in software project management: are we alone? A comparison with construction industry. J Modern Project Manage. 2014; 2(1):22-7.

27 Jugdev K, Muller R. A retrospective look at our evolving understanding of project success. Proj Manage J. 2015;36(4):19-31.

28 Munns A, Bjeirmi B. The role of project management in achieving project success. Int J Proj Manag. 1996;14(2):81-7.

29 Ika L. Project success as a topic in project management journals. Proj Manage J. 2009; 40(4):6-19.

30 Bourne L, Walker D. Advancing project management in learning organizations. Learn Organ. 2004;11(3):226-43.

31 Al-Tmeemy S, Abdul-Rahman H, Harun Z. Future criteria for success of building projects in Malaysia. Int J Proj Manag. 2010;29(3): $337-48$.

32 Jaafari A. Management of risks, uncertainties and opportunities on projects: time for a fundamental shift. Int J Proj Manag. 2001;19(2): $89-101$.

33 PMI. A guide to the project management Body of Knowledge. 6th ed. revised. Philadelphia (PA): Project Management Institute; 2017.

34 Perminova O, Gustafsson M, Wikstrom K Defining uncertainty in projects: a new perspective. Int J Proj Manag. 2008;26(1):73-9.

35 Schwalbe K. Information technology project management. 6th ed. revised. Boston (MA): Course Technology; 2011.
36 Cooke-Davies T. The "real" success factors on projects. Int J Proj Manag. 2002;20(3):18590.

37 Pinto J, Slevin D. Project success: definitions and measurement techniques. Proj Manage J. 1988;19(1):67-72.

38 Standish Group. Project resolution benchmark report. 2018 [cited 2018 Apr 3]. Available from: https://www.standishgroup.com/ sample_research_files/DemoPRBR.pdf.

39 Abdullah AA. Literature mapping: a bird's eye view on classification of factors influencing project success. Afr J Bus Manag. 2010;(4): 4174-82.

40 Davis K. Different stakeholder groups and their perceptions of project success. Int J Proj Manag. 2014;32(2):189-201.

41 Diallo A, Thuillier D. The success of international development projects, trust and communication: an African perspective. Int J Proj Manag. 2005;23(3):237-52.

42 Khang D, Moe T. Success criteria and factors for international development projects: a lifecycle-based framework. Proj Manage J. 2008 39(1):72-84.

43 Edward J, Kinlaw CS, Kinlaw DC. Developing superior project teams: a study of the characteristics of high performance in project teams. PMI ${ }^{\circledR}$ Research Conference "Project management research at the turn of the millennium", 21-24 June 2000, Paris, France. Newtown Square: Project Management Institute; 2000.

44 Tansley C, Newell S. Project social capital, leadership and trust: a study of human resource information systems development. J Manage Psychol J Manage. 2007;22(4):35068.

45 Glaser J. Management's role in IT project failures. Healthc Financ Manage. 2004 Oct; 58(10): $90-2$.

46 Simpson J. The state of requirements management: the report [Internet]Portland: Jama Software; 2009. [ [cited 2013 Oct 13]], Available from http://it-consulting.pl/autoinstalator/wordpress/wp-content/uploads/ 2011/10/2011-State-of-Requirements-Management-Report.pdf

47 Yalegama S, Chileshe N, Ma T. Critical success factors for community-driven development projects: a Sri Lankan community perspective. Int J Proj Manag. 2016;34(4):64359.

48 Golini R, Kalchschmidt M, Landoni P. Adoption of project management practices: the impact on international development projects of non-governmental organizations. Int J Proj Manag. 2015;33(3):650-63.

49 Ika L, Donnelly J. Success conditions for international development capacity building projects. Int J Proj Manag. 2017;35(1):44-63.

50 Chen H, Lin Y. Goal orientations, leaderleader exchange, trust, and the outcomes of project performance. Int J Proj Manag. 2018; 36(5):716-29. 
51 Payne JM, France KE, Henley N, D’Antoine HA, Bartu AE, Elliott EJ, et al. Researchers' experience with project management in health and medical research: results from a post-project review. BMC Public Health. 2011 Jun;11(1):424-34.

52 Medlin C, Chowdhury M, Jamison DT, Measham A. Chapter 8: Improving the health of populations: lessons of experience. In: Jamison DT, Breman JG, Measham AR, et al, editors. Disease control priorities in developing countries. 2nd ed. Washington, DC: World Bank; 2006.

53 Cheadle A, Hsu C, Schwartz PM, Pearson D, Greenwald HP, Beery WL, et al. Involving local health departments in community health partnerships: evaluation results from the partnership for the public's health initiative. J Urban Health. 2008 Mar;85(2):162-77.
54 World Health Organization. Priority-setting for national health policies, strategies and plans. Strategizing national health in the 21st century: a handbook. Geneva: WHO; 2016.

55 Rifkin SB, Lewando-Hundt G, Draper AK. Participatory approaches in health promotion and health planning: a literature review. London: Health Development Agency; 2000.

56 Tempfer CB, Nowak P. Consumer participation and organizational development in health care: a systematic review. Wien Klin Wochenschr. 2011 Jul;123(13-14):408-14.

57 Dwyer J, Stanton P, Thiessen V. Project management in health and community services: getting good ideas to work. London: Routledge; 2004.

58 Paré G, Trudel MC. Knowledge barriers to PACS adoption and implementation in hospitals. Int J Med Inform. 2007 Jan;76(1):2233.
59 Suhonen M, Paasivaara L. Nurse managers' challenges in project management. J Nurs Manag. 2011 Nov; 19(8):1028-36.

60 US Department of Health and Human Services. CDC: Project management - supporting a common project delivery framework. 2007 [cited 2018 Jan 21]. Available from: https://www2a.cdc.gov/cdcup/library/newsletter/CDC_UP_Newsletter_v1_i1.pdf.

61 Silvestre J, Bowers B, Gaard S. Improving the quality of long-term care. J Nurs Regul. 2015; 6(2):52-6.

62 Varajão J. Success management as a PM knowledge area: work-in-progress. Procedia Comput Sci. 2016;100:1095-102.

63 Varajão J. New process for success management: bringing order to a typically ad-hoc area. J Mod Proj Manag. 2018;5(3):92-9. 